\title{
Review Essay: The War System in Colombia: The Interpretations of Nazih Richani and James Rochlin
}

Richani, Nazih. Systems of violence: the political economy of war and peace in Colombia

Albany: State University of New York Press, 2002.

164

Rochlin, James. Vanguard revolutionaries in Latin America: Peru, Colombia, Mexico

Colorado: Lynne Rienner Publishers, 2003.

The civil war in Colombia has touched all aspects of its political, social, economic and cultural life. The endurance of the war has created instability in the domestic sphere, while in the international arena, the conflict has provided consistency in foreign perceptions of Colombia. Colombia has been identified as a violent, brutal and dangerous place not only for foreigners, but for Colombians themselves. From the early 1960s into the $1980 \mathrm{~s}$ armed actors representing both the State and 'the people' have struggled to implement their own vision of the future, and arguably, their own version of the past. With the increased profitability of narcotic sales in the 1980s and 1990s new armed actors entered the scene as the security agents of the rich and powerful, thereby contributing to the polarization of the country's socioeconomic groups and the malignancy of the civil war. These two spaces of time, the $1960 \mathrm{~s}-1980$ s and the 1980 s to the present day, witnessed the solidification of a protracted 
system of warfare in Colombia and the further legitimization of violence as a technique of conflict resolution.

Nazih Richani and James Rochlin, two scholars of Colombian and Latin American affairs, have examined the development of the war system in Colombia by looking at its historical antecedents and twentieth century manifestations. In Richani's 2002 work, Systems of violence : the political economy of war and peace in Colombia, and Rochlin's 2003 work, Vanguard revolutionaries in Latin America: Peru, Colombia, Mexico, the two scholars come to similar conclusions, but with different goals and by the utilization of different political science theoretical approaches. In this essay I will characterize the war system interpretations of Richani and Rochlin by examining the objectives, similarities and differences of their writing. Both writers bring a unique perspective to the understanding of the Colombian conflict and argue that it has been Colombian democracy and civil society that have suffered the most due to excessive levels of warfare and violence. While the two scholars argue about the durability of the system and the possibility of its collapse, it is clear from the interpretations of Richani and Rochlin that the Colombian civil war is a complex and influential determinant of politics and society.

Before comparing the interpretations of Richani and Rochlin it is necessary to discuss the objectives and central arguments of their work. A writer's intent is important in the comprehension of his argument because it informs the reader of the 'slant' of his writing; in other words, his argument is a reflection of his purpose in researching and writing the work. Overall, Richani's and Rochlin's objectives in exploring the Colombian conflict reflect their different theoretical approaches 
to the study of political science. Nazih Richani aspires to understand the social and political conditions of Colombia's war system by focusing on the armed actors independently, but within the interconnected environment of the conflict. He writes that the civil war cannot be understood

without exploring the interconnection among its 166 main actors... and without evaluating variables such as contingencies, social structures, and agencies that shape the actors environments and in turn affect their behaviour. ${ }^{1}$

In essence, within the institutions of the State military, the guerrillas and the paramilitaries, there are individuals who make rational choices to protect their own interests, within the set political and social structures of their organizations. "The war system is an outcome of actors' behaviour and is not necessarily their optimal goal", argues Richani, "[b]ut since the balance of power did not allow [the establishment of a single hegemonic power] actors adjusted their goals and strategies". ${ }^{2}$ It is the interaction between these goals and behaviours that have solidified and protracted the civil war. Richani's analysis looks at the different institutions of armed actors from a political sociological approach, as he looks at social relations within the groups - the course and effect of social action and choice-and relates them to the bigger problems of the war. However, he also seems to incorporate a political economic approach when he looks at the groups within the context of the war as a whole. By looking at the military, the guerrillas and the paramilitaries as 'states within a state' he examines the war system by looking at the relationship

\footnotetext{
${ }^{1}$ Nazih Richani, Systems of violence: the political economy of war and peace in Colombia, (Albany: State University of New York Press, 2002): 152.

${ }^{2}$ Ibid.

Past Imperfect

14 [2008) | ( ) |ISSN 1711-053X | elSSN 1718-4487
} 
between their economic and political power and the "impasse" of the 80 s and $90 \mathrm{~s}^{3}$ How these groups have affected each other, the political environment and political culture is reflected in the balance of power evident in the $60 \mathrm{~s}$ and $70 \mathrm{~s}$, and the greater instability of the $80 \mathrm{~s}$ and $90 \mathrm{~s}$.

Similarly, Rochlin seeks to explain the social and political structures of Colombia that have contributed to the war system. However his objectives differ with Richani's in respect to his focus on the violence of the war system and how violence and brutality have become a way of life. For Rochlin, the war system is the routinization of excessive violence by its use as political discourse. He asks, "[h]ow have Colombian social structures accentuated violence to the point that it has become a way of life?" and how has violence in Colombia demonstrated the necessity of "good government"? 4 Since Rochlin is looking at the "vanguard revolutionaries" of Peru, Colombia and Mexico, his conception of the Colombian conflict is that the armed actors are struggling toward a revolutionary goal, and he focuses extensively on the two leftist guerrilla movements. He looks at guerrilla "strategy, security and power" in competition with an inept State; he argues that a political culture of violence and a premodern system of thought permeate the guerrilla ranks and the civilian populations. ${ }^{5}$ Thus, in contrast to Richani's approach, Rochlin looks at the political culture of Colombia as the explanatory variable in the war system. The attitudes, values and orientations that the individuals of civil society and guerrilla society hold regarding the capabilities of the State are important to Rochlin

3 Ibid., 133

${ }^{4}$ James Rochlin, Vanguard revolutionaries in Latin America : Peru, Colombia, Mexico, (Colorado: Lynne Rienner Publishers, 2003): 87, 119.

5 Ibid., 119. 
because, as his historical outline indicates, violence has been socialized and legitimated through life experience and formal and informal education. Now that it is clear what the objectives and theoretical framework of Richani's and Rochlin's interpretations are we can proceed to discuss the similarities and differences of their characterizations of the Colombian imbroglio.

168| There are three integral similarities in the analyses of Richani and Rochlin; both argue that the war system has been institutionalized, that the internal organization of the armed actors and State apparatus are intimately connected to the protraction of the war, and they both highlight the influential entrance of the narco-traffickers and paramilitaries into the conflict, in the late $80 \mathrm{~s}$ and early $90 \mathrm{~s}$. As a result of the unprecedented duration, endurance and vehemence of the armed struggle, both Richani and Rochlin argue that war and violence have been institutionalized. Rochlin follows the history of Colombia from its independence until the present, and he argues that it was La Violencia of 1946-1958 which "reintroduced violence as a way of life - an orientation to dealing with conflict reminiscent of the previous century". 6 Similarly, Richani writes that the increased power allocated to the military during the National Front government, and after La Violencia permitted war to become institutionalized because the " interests of the military became articulated around a strategy of low-intensity war, allowing an uneasy coexistence with the guerrillas". 7 Paradoxically, while violence became an outlet for conflict resolution, the promulgation of a low-intensity conflict and accepted coexistence, war and violence did not resolve any

${ }^{6}$ Ibid., 96.

7 Richani,_Systems of violence, 42. 
disputes, but instead allowed war to progress into stalemate and a subsequent attitude of 'business as usual'.

The organization of the armed enterprises also contributed to the entrenchment of a violent war system. Richani and Rochlin both agree that the strategies of the military and the guerrillas in their efforts to gain an advantage over the other in a low-intensity war equipped them with mechanisms that prolonged the conflict, and made it bearable for the 'long haul'. For Richani these strategies created a "positive political economy" (PPE) within the armed groups. For the military, its increased role as the promoters of stability in Colombia during the National Front government led to the bloating of the bureaucratic structure, a monopoly on force and the ability of the military to influence political policy without ever co-opting power. ${ }^{8}$ The militaries ability to organize in this way was prompted by the State's inability and refusal to carve out a legitimized relationship with armed players after La Violencia. The legacy of this situation is reflected in the antagonisms of the various spheres of power operating in Colombia's rural and urban environments; the lack of legitimacy and a surplus of frustration with the State apparatus after La Violencia have resulted in a fractured power system. The State, the guerilla and the paramilitary seek to destroy each other, but their existence relies on the persistent and entrenched system of demonizing the enemy and inciting populist warfare. Rochlin focuses more intently on the transformation of Fuerzas Armadas Revolucionarias de Colombia (Revolutionary Armed Forces of Colombia or FARC) and Ejército de Liberación Nacional (National Liberation Army or ELN) strategies in regards to power

\footnotetext{
${ }^{8}$ Ibid., 41-47.

Past Imperfect 14 [2008) |@ |ISSN 1711-053X| | ISSN 1718-4487
} 
seizure. The organization of guerrilla enclaves has reflected a premodern conception of "power over" strategic space, and they have successfully taken control over small regions in Colombia with an idea of "localized constellation[s] of power".

Lastly, both Richani and Rochlin write that as a result of the further participation of paramilitaries in the conflict, fighting 170 on behalf of narco-traffickers and other large landowners, changes could be on the horizon within the war system. For Richani, the bipolar war system had allowed both the military and the guerrillas to consolidate political and economic gains, and thereby, the "uneasy coexistence" remained in place. The entrance of paramilitaries into the equation has created a multi-polar dynamic, and has destabilized the war system. The paramilitaries role in protecting traffickers and powerful cartel leaders have increased the costs of war, in terms of investment and the incorporation of Colombia into global markets, and thus, dominant powers especially in the urban centers are rethinking the advantages of negotiated peace. ${ }^{10}$ Rochlin also sees the 'paras' and 'narcos' as important actors in the breakdown of the system of war and violence. Although violence has been the common denominator of the military and the guerrillas since the $60 \mathrm{~s}$, the massacres and the consequent fragmentation of political power prompted by the new subversive group has enflamed the animosity between groups. ${ }^{11}$ However, Rochlin is not quite as optimistic as Richani about the chances for peace in regards to paramilitary activity. While he believes that a "rupture" has occurred in Colombia since the mid-to-late 80s, in Rochlin's

\footnotetext{
9 Rochlin,_Vanguard revolutionaries, 157.

${ }_{11}$ Richani, Systems of violence, 122-155.

11 Rochlin,_Vanguard revolutionaries, 145-149. 
opinion, the further fragmentation and dispersion of power will only lead to more coercion and warfare-not negotiated peace or social consent. He writes that it has been

difficult to identify the proverbial good guys...Each of Colombia's belligerents have used so much horrific force and committed so many political blunders that there has been no clear hero on the scene. ${ }^{12}$

This is problematic because civil society will only continue to get weaker and weaker, and the State can provide no protection or comfort to those surrounded by constant war and violence.

Although their similarities are important, Richani's and Rochlin's differences provide new perspectives on the study of Colombia's civil war. Besides their different theoretical perspectives discussed above, there are two major differences in these authors interpretations: their diagnoses of what the armed groups deem as necessary for group survival and how the war system was created. Indicative of his argument that the entrance of the multi-polar war front has destabilized the war system, Richani argues that a positive political economy (PPE) within the armed groups is necessary for their continued fighting capabilities and their ultimate survival as legitimate players. For the guerrillas, this means that they must continue receiving rent and taxes from coca producers but more importantly, they must keep control of vital regions of the country. ${ }^{13}$ For the military, the shift to a high-intensity war in the $90 \mathrm{~s}$ has meant that their institutional setup has destabilized and their power in the political process has diminished, although not completely. ${ }^{14}$ The PPE of the guerrillas

12 Ibid., 160-161.

13 Richani,_Systems of violence, 59.

14 Ibid., 47.

$$
\begin{gathered}
\text { Past Imperfect } \\
14 \text { [2008) | (C) |ISSN 1711-053X | elSSN 1718-4487 }
\end{gathered}
$$


and military has been disrupted as both war institutions had to respond to a more intense conflict, and the entrance of a new group which desired its own share of the resources of the State. ${ }^{15}$ Rochlin makes no mention of the necessity of the PPE, but argues that it was necessary for the military, guerrillas and 'paras' to sustain their military machines by increased violence and 172| brutality in order to survive the new war. ${ }^{16}$ The focus on military prowess reflects the historical antecedents of the conflict as well as the notions of premodernity held by guerrilla groups. Increasingly, the conflict revolves around strategic sites around the country, and if an armed group cannot hold that site through force and violence, then that group will not be considered a formidable opponent. ${ }^{17}$

Another difference in Richani's and Rochlin's Colombian accounts is their examination of how the war system itself was created. It has already been mentioned that both writers believed that the war system was thoroughly entrenched and ingrained in the political, social, economic and cultural institutions of the country. It had in fact, been institutionalized itself. However Richani argues that the system was created by the incompetence of the State, while Rochlin argues that it has evolved from a long history of conflict and violence in Colombia. Through a reading of Richani it is apparent that the lack of State presence in the hinterlands of the country after La Violencia and the National Front's refusal to engage in any military strategy, enabled the military to maintain an ideology of warfare after the hostilities of La Violencia had subsided, and allowed the guerrillas to create a

\footnotetext{
${ }^{15}$ Ibid., 57.

${ }_{17}^{16}$ Rochlin,_Vanguard revolutionaries, 112-115.

${ }^{17}$ Ibid.
} 
strong support base in the rural parts of the country. Thereby, with the incentive of the PPE, the war system was created right before the eyes of the National Front government. The trajectory of violence continued and gradually came to stalemate, until the $80 \mathrm{~s}$ and 90s. Rochlin argues that this view is not accurate; it fails to appreciate the historical legacies of brutality, bipartisan violence and prolonged war. Violence had been used as a legitimate expression of political discourse since the independence period. Warfare and violence in Colombia socialized every generation of Colombians, rendering the guerrilla groups and the military more interested in armed struggle and violent confrontation, than on political or ideological development. ${ }^{18}$ Moreover, this notion of legitimacy has never been challenged; the horrific failure of the Unión Patriótica (Patriotic Union or UP) in the early 80s has convinced many armed actors that the State has no intention of promoting political tolerance. A political party founded by members of the FARC in the mid-1980s, the UP consisted of former guerillas attempting to negotiate peace in the political realm. Violent attacks from paramilitaries, drug-cartels and other political opponents rendered this group virtually inconsequential by the 1990s. More importantly still, the assassination of UP candidates and officials has further convinced armed actors that the State is powerless to implement politically inclusionary policies. Therefore, political and ideological development is useless, violence, on the other hand, remains a powerful educational tool in lessons of power, control and legitimacy.

Richani and Rochlin are both incredibly insightful and knowledgeable analysts of the war system in Colombia. Although

18 Ibid., 112.

$$
\begin{gathered}
\text { Past Imperfect } \\
14 \text { [2008] | @ | ISSN 1711-053X | elSSN 1718-4487 }
\end{gathered}
$$


the objectives of their works may differ, both provide passionate interpretations of Colombia's conflict, and engage the reader in different political science approaches to understanding the civil war. Richani separates the violence of the country from the conflict, and focuses on the individuals within the armed groups to understand the functioning of each organization. Subsequently, he 174 examines these groups in relation to each other, and infers from their behaviour the effect armed struggle has had on creating a war system. He blends a political sociology and economy approach to provide a unique reading of the civil war. Rochlin on the other hand, uses a political culture approach. He points to the enduring violence of the Colombian past and its socialization within the Colombian way of life, and posits that it is the institutionalization of violence that has perpetuated the war system. Violence has prompted the creation of war machines, and has allowed armed actors' to be politically viable considerations in the domestic and international spheres. After reading and digesting these two persuasive analyses, it is difficult to come to any conclusion on which one is more relevant than the other. Certainly, Richani's outlook is more optimistic for the future, but it is difficult to agree with him considering the long history of violence and protracted warfare in Colombia. It is just as likely that war will continue to haunt the civilian populations and hinder the development of true democracy.

Lindsay Sidders-Hodgins, University of Alberta

Past Imperfect

14 (2008) | (C) |ISSN 1711-053X| eISSN 1718-4487 